\title{
THE PERFORMANCE OF LOW FEE INDEPENDENT SCHOOLS IN SOUTH AFRICA - WHAT CAN AVAILABLE DATA TELL?
}

SERVAAS VAN DER BERG, CHRIS VAN WYK, RONELLE BURGER, JANELI KOTZÉ, MARLIES PIEK \& KATE RICH

\section{Stellenbosch Economic Working Papers: 01/17 January 2017}

KEYWORDS: PUBLIC AND INDEPENDENT SCHOOLS, LOW FEE SCHOOLS JEL: I21, I24

ReSEP (Research on Socio-Economic Policy), Department of Economics, University of Stellenbosch

SERVAAS VAN DER BERG DEPARTMENT OF ECONOMICS UNIVERSITY OF STELLENBOSCH PRIVATE BAG X1, 7602

MATIELAND, SOUTH AFRICA SVDB@SUN.AC.ZA

CHRIS VAN WYK DEPARTMENT OF ECONOMICS UNIVERSITY OF STELLENBOSCH PRIVATE BAG X1, 7602 MATIELAND, SOUTH AFRICA CHRISVAN WYK@SUN.AC.ZA

JANELI KOTZÉ

DEPARTMENT OF ECONOMICS UNIVERSITY OF STELLENBOSCH PRIVATE BAG X1, 7602

MATIELAND, SOUTH AFRICA JANELI.KOTZE@GMAIL.COM
RONELLE BURGER

DEPARTMENT OF ECONOMICS

UNIVERSITY OF STELLENBOSCH

PRIVATE BAG $X 1,7602$

MATIELAND, SOUTH AFRICA

RBURGER@SUN.AC.ZA

MARLIES PIEK

DEPARTMENT OF ECONOMICS

UNIVERSITY OF STELLENBOSCH

PRIVATE BAG X1, 7602

MATIELAND, SOUTH AFRICA

MARLIESR@SUN.AC.ZA

KATE RICH

DEPARTMENT OF ECONOMICS

UNIVERSITY OF STELLENBOSCH

PRIVATE BAG $X 1,7602$

MATIELAND, SOUTH AFRICA

KATETAMARINRICH@GMAIL.COM 


\title{
THE PERFORMANCE OF LOW FEE INDEPENDENT SCHOOLS IN SOUTH AFRICA - WHAT CAN AVAILABLE DATA TELL?
}

\author{
SERVAAS VAN DER BERG, CHRIS VAN WYK, RONELLE BURGER, JANELI KOTZÉ, \\ MARLIES PIEK \& KATE RICH
}

\begin{abstract}
This study analysed grade 6 and grade 9 mathematics data from the Annual National Assessment by comparing school performance in public and independent schools in three geographical regions: Western Cape, Gauteng and South Africa as a whole. The aim was to see whether low-fee independent schools outperform public schools i) for schools which have similar school fees and ii) for schools which have similar resources, which is the sum of school fees and government subsidies.

Our analysis indicates that independent primary schools, in all three geographical regions, are able to use resources more efficiently and are thus able to translate resources into better performance. However, when comparing schools in similar school fee brackets, the findings are mixed and vary by geographical area: sending a child to an independent primary school in Gauteng is worthwhile, whereas it is not worthwhile in the Western Cape.
\end{abstract}




\section{CONTENTS}

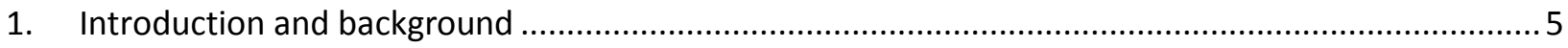

2. Low fee independent schools in the international literature ........................................................

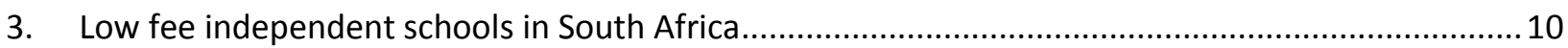

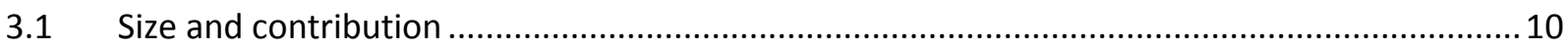

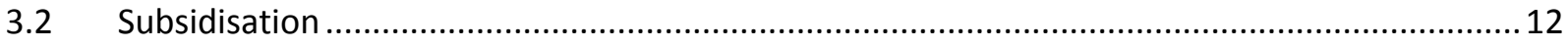

3.3 Regulating and monitoring independent schools ............................................................. 14

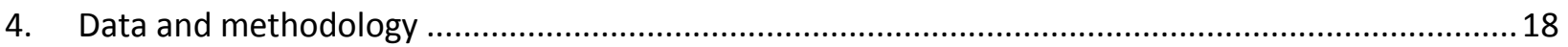

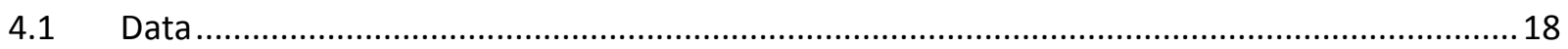

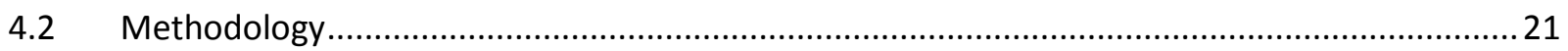

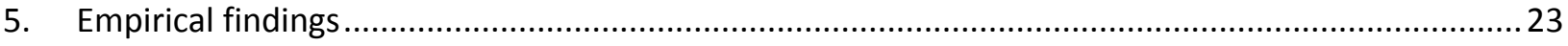

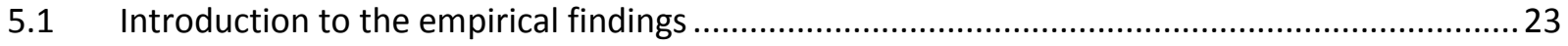

5.2 Findings related to resources (school fees plus subsidies) ....................................................23

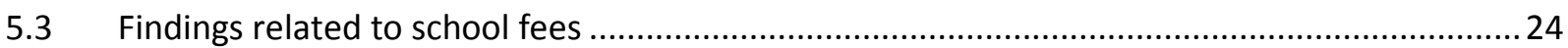

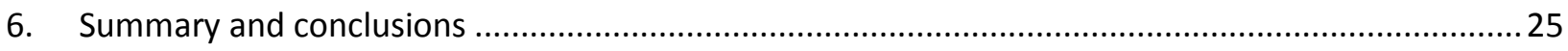

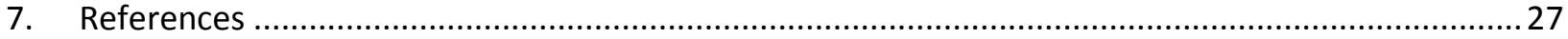


Table 1: Some rigorous estimates of the impact of private schools in developing countries

Table 2: Racial composition of independent and public schools, 2012.

Table 3: Subsidies per learner in ordinary public schools.

Table 4: Registered independent schools in the Western Cape by school fee decile and participation in ANA, 2014

Figure 1: Resources available per child in no fee schools, subsidised independent schools, fee-paying public schools and unsubsidised independent schools (fees only)

Figure 2: Resources available per student in independent schools as percentage of resources in public schools 14

Figure 3: Distribution of ANA Mathematics scores for public and independent school, all schools and quintile 8 and 9 schools only, 2012. 20 


\section{INTRODUCTION AND BACKGROUND}

In the context of South Africa's failing school system, an important question is what options independent fee-paying schools can offer to parents who are willing to commit more private resources in order to improve their children's chances of obtaining a good education. The quality of low fee independent schools is of considerable importance from the perspective of a parent in an impoverished community who values education and is willing and able to commit resources to sending their child to a better school. According to household surveys such parents appear to be exceptional, but not rare, constituting up to $8 \%$ of parents living in poor communities. Such households make considerable sacrifices, yet anecdotal evidence suggests that these sacrifices often may not yield the envisaged benefits because the preferred school may not be significantly better than the default school. While the Annual National Assessments (ANA) can provide a basis to parents for comparing performance across schools (though there are issues with data quality), it is rarely used for such comparisons. Consequently, parents are often left with very little information to guide their pursuit of a better quality education for their child, leaving them to resort to basing their choice on a combination of rumour, stereotype and pragmatic considerations.

Economic and organisational theory would suggest that independent schools may be able to provide better value for parents' money than government schools. Teachers and principals at for-profit independent schools may for instance be more motivated due to better performance management at such schools, and non-profit independent schools may also succeed in attracting or recruiting principals and teaching staff with higher intrinsic motivation and commitment to the school's mission. Additionally, the accountability relationships between parents and school staff are simpler and therefore likely to be more easily aligned in independent than in public schools. Organisational theory also suggests that the enhanced freedom of greater organisational independence in independent schools compared to state schools that are part of a large and sluggish government bureaucracy may promote customisation, client responsiveness and innovation and should help to facilitate tighter feedback and learning loops. An earlier report by the Centre for Development and Enterprise (CDE, 2010) provided some preliminary evidence to support this hypothesis. This study compared independent and public schools in six selected areas across three provinces, but it is not possible to ascertain whether differences in results could be driven primarily by private schools' higher level of resources, the attraction of higher ability, more motivated or more affluent students, or better teaching.

This study was undertaken to provide further information on whether there is systematic evidence that independent schools, or a substantial proportion of them, perform significantly better than comparable public schools in terms of cognitive outcomes. Ideally, a study was sought that would also indicate whether such better performance, if it happened to be found, was the result of greater resource availability, parent motivation, or school functionality. But from the outset it was clear that data issues may limit the ability to undertake such a sophisticated analysis and the research team cautioned that there were necessarily limitations to the results that can be obtained. Moreover, evidence from the USA on charter schools - which seem to offer some of the same potential gains from the use of incentives, accountability structures and management that one would hope for in South African independent schools - have not yielded strong evidence of enhanced performance, though recent results indicate that this may be because of a lag in performance improvement. 
The study is in the first place an empirical one that attempts to determine how much evidence can be brought to bear from existing data on the relative performance of independent schools. However, a thorough survey of the international literature was also conducted as a background to this study, and it is summarised in Part 2, that deals with international evidence. Part 3 summarises the South African evidence, whilst Part 4 describes the data and the methodology adopted. The empirical findings are contained in Part 5, and Parts 6 deals with the summary and conclusions. 


\section{LOW FEE INDEPENDENT SCHOOLS IN THE INTERNATIONAL LITERATURE}

Many developing countries face chronically low levels of learning in the public schooling system. At the same time, developing countries have experienced a significant growth in private schooling within the last few decades. Between 1990 and 2010, enrolment in private primary schools as a percentage of total primary enrolments doubled from 11 percent to 22 percent in low-income countries. Private school enrolments now make up over 20 percent of total enrolments in more than 70 countries (Baum et al., 2014:8). Private schools are often regarded as the preserve of the rich. However, a striking aspect of the growth in private schooling has been the proliferation of low-fee private schools serving relatively poor families. This has sparked significant debate over the role of such schools, with some decrying the privatisation of a function they think best left to the state, and others applauding the ability of the private sector to fill the gap created by the underperformance of the state schooling system. It has also inspired a growing body of research into the relative performance of private and public schools in developing countries. There is substantial evidence from both developed and developing countries that private school students perform better academically than their government school counterparts. However, private school students are also likely to be wealthier and come from a home background more conducive to academic success, so it is not immediately clear whether the observed better performance of private school students is due to the effect of private schooling itself or due to the effect of the characteristics associated with private school attendance. This section will review the literature on private schools in developing countries, focusing on the low-cost variety, and the attempts to estimate the true effect of private schooling on educational outcomes.

One possible source of the better performance of learners in private schools than government schools in developing countries that is consistent with economic theory is that private schools provide principals and teachers with stronger incentives for good performance than in the public system. The remuneration structure for teachers in government schools is often fairly flat and dependent on teacher experience rather than effort or performance. Furthermore, it is difficult to fire publicly employed teachers, so there is limited threat of teachers losing their jobs because of poor performance. There is thus little incentive for good performance in government schools. In private schools, on the other hand, the survival of a school is dependent on parents continuing to send their children there. The school management has a strong incentive to ensure good performance, as they face the threat of parents removing their children from the school and losing the revenue from their fees. Private school teachers can also be fired much more easily, so they have a stronger incentive to work hard. School management thus has more control over teacher effort, and private schools are in theory more accountable to parents.

The demand for private schooling is often driven by dissatisfaction with the quality of education available in the public system (push factors) as well as the perception that private schools offer a higher quality education and better life chances for children (pull factors). In interviews parents who send their child to a private school often mention high teacher absenteeism, low accountability and poor performance as some of the factors driving them away from the public system. Perceived greater accountability and better performance and, in some countries and contexts, instruction in English were among the factors attracting parents to private schools. 
The international literature indicates that low-fee private schools usually employ younger, less experienced and less qualified (but sometimes more educated) teachers than government schools. These teachers are then usually paid far lower salaries than government school teachers. Nonetheless, private schools tend to have better teaching conditions than government schools, with lower pupil-teacher ratios, lower rates of teacher absenteeism, and greater teaching activity. Furthermore, there is substantial evidence from a range of countries that private school students achieve higher scores than those in government schools. The challenge is to determine whether these higher scores are merely due to private schools having a greater share of "good" students, or whether they reflect a true effect of attending a private school.

A relatively small but growing literature has attempted to estimate the impact of low-fee private schools in developing countries, with the majority of such studies focusing on India. These studies use various econometric techniques to attempt to control for any ways in which private school students differ from government school students that are also related to education outcomes, such as home background, natural ability and parental motivation. Most studies have found at least some positive effect of attending a private school, though the effect sometimes differs by subject or location. The table below summarises some of the most rigorous estimates of the impact of private schools in developing countries.

It appears from this table that the positive impact of private schools is quite widely encountered, but that this is far from universal, and that the effect sizes are not always very large. Many of these studies cannot wholly control for the effect of selection bias, i.e. that the children who attend such private schools end up there because they, or their parents, are different, in terms of motivation, resources or ability. It is thus difficult to know the counterfactual, i.e. how well they would have performed in public schools. Only the randomised control trials can in principle avoid this sample selection issue, though the other rigorous methods used in the studies summarised here all try to reduce this effect: by comparing students in private and public schools who are similar in many observed criteria (propensity score matching): by correcting for the observed dissimilarities between students (Heckman sample correction): or by controlling for students' previous performance before they moved to private schools (fixed effects method).

In many cases private schools are able to achieve similar or better results than government schools at a significantly lower cost. This is largely due to the fact that private school teachers in low income countries are usually paid much lower salaries, and suggests that private schools can be cost-effective. Nonetheless, a number of concerns have been raised regarding the proliferation of private schools.

One of the criticisms levelled at private schooling is that because it is not free it favours the rich and thus promotes inequality. A related criticism is that it is unaffordable for the poor, and that families may have to make large sacrifices in order to send their children to private schools. The evidence suggests that while more affluent families are more likely to send their children to private schools, a substantial number of poor families are still able to access low-fee private schools. However, this does not necessarily mean that these schools are truly affordable for them. Several studies provide evidence that sending children to private schools takes up a large proportion of the income of poor households and may lead to them having to sacrifice spending on other necessary items, such as health. 
Table 1: Some rigorous estimates of the impact of private schools in developing countries

\begin{tabular}{|c|c|c|c|}
\hline Study & Country & Method & Size of effect \\
\hline $\begin{array}{c}\text { Chudgar \& Quin } \\
\text { (2012) }\end{array}$ & India & $\begin{array}{c}\text { Propensity score } \\
\text { matching }\end{array}$ & $\begin{array}{l}\text { Reading: } 0.22 \text { (measured on a scale of 0-4) } \\
\text { in rural sample, no effect in urban sample } \\
\text { Writing \& maths: no effect }\end{array}$ \\
\hline Thapa (2012) & Nepal & $\begin{array}{c}\text { Propensity score } \\
\text { matching }\end{array}$ & 10.56 percentage points \\
\hline Kingdon (1996) & $\begin{array}{l}\text { Uttar Pra- } \\
\text { desh, India }\end{array}$ & $\begin{array}{l}\text { Heckman two-step } \\
\text { sample correction }\end{array}$ & $\begin{array}{l}\text { Maths: } 1.42 \text { points (out of } 36 \text { ) } \\
\text { Reading: } 0.04 \text { points (out of } 29 \text { ). }\end{array}$ \\
\hline Desai et al. (2008) & India & $\begin{array}{l}\text { Heckman two-step } \\
\text { sample correction }\end{array}$ & \pm 0.25 Standard Deviations \\
\hline Desai et al. (2008) & India & Fixed effects & \pm 0.25 Standard Deviations \\
\hline $\begin{array}{l}\text { French \& Kingdon } \\
(2010)\end{array}$ & India & Fixed effects & 0.17 Standard Deviations \\
\hline $\begin{array}{l}\text { Javaid, Musaddiq \& } \\
\text { Sultan (2012) }\end{array}$ & Pakistan & Fixed effects & 0.038 Standard Deviations \\
\hline $\begin{array}{l}\text { French \& Kingdon } \\
\text { (2010) }\end{array}$ & India & (Village-level) panel & 0.114 Standard Deviations \\
\hline Singh (2013) & $\begin{array}{l}\text { Andhra } \\
\text { Pradesh, } \\
\text { India }\end{array}$ & Panel & $\begin{array}{c}\text { Urban areas: no effect } \\
\text { Rural areas, } 8-9 \text { year olds: } \\
\text { Vocabulary: } 0.17 \text { Standard Deviation } \\
\text { English: } 0.7 \text { Standard Deviations } \\
\text { Maths: no effect } \\
\text { Telugu: negative effect } \\
\text { Rural areas, } 15 \text { year olds: } \\
\text { Vocabulary \& Telugu: } 0.12 \text { Standard } \\
\text { Deviations } \\
\text { Maths: } 0.2 \text { Standard Deviations }\end{array}$ \\
\hline Andrabi et al. (2011) & $\begin{array}{l}\text { Punjab, } \\
\text { Pakistan }\end{array}$ & Dynamic panel & 0.25 Standard Deviations per year \\
\hline Angrist et al. (2002) & Colombia & $\begin{array}{c}\text { Randomised } \\
\text { evaluation }\end{array}$ & 0.2 Standard Deviations \\
\hline $\begin{array}{l}\text { Muralidharan \& } \\
\text { Sundararaman } \\
\quad(2013)\end{array}$ & $\begin{array}{l}\text { Andhra } \\
\text { Pradesh, } \\
\text { India }\end{array}$ & $\begin{array}{l}\text { Randomised } \\
\text { evaluation }\end{array}$ & $\begin{array}{c}\text { 0.13 Standard Deviations overall } \\
\text { Telugu \& maths: no effect } \\
\text { English: } 0.12 \text { Standard Deviations } \\
\text { Social studies: } 0.08 \text { Standard Deviations } \\
\text { Hindi: } 0.55 \text { Standard Deviations }\end{array}$ \\
\hline
\end{tabular}

Another concern is the potential effect that the growth of private schools could have on government schools and the children who get left behind in the public system. The flight of middle class or more able children from the public school system to private schools may reduce the accountability of government schools and the pressure on them to improve, thus driving down the quality of government schools. It is rather difficult to evaluate this claim, but the limited available evidence offers no support for this notion. 


\section{LOW FEE INDEPENDENT SCHOOLS IN SOUTH AFRICA}

\subsection{Size and contribution}

There has been very limited South African research on low-fee independent schools. The existing literature is limited to descriptive analyses of the scope, growth and potential of South Africa's low-fee independent school sector. As yet no studies have attempted a rigorous assessment of the relative effectiveness of South Africa's low-fee independent schools.

The South African private school sector has grown rapidly from a low base in the last 15 years. According to official statistics summarised by Draper and Hofmeyr (2015:12), independent school enrolments grew from around 250000 to 500000 between 2000 and 2013. Hofmeyr et al. (2013:6) find that private school enrolment grew by $75.9 \%$ between 2000 and 2010 compared to only $1.4 \%$ in government schools. Moreover, Draper and Hofmeyr (2015:12) state that there has been a major demographic shift in the composition of the independent school sector, from being mainly white and serving the rich to being mainly black and the majority of schools now serving low- and middle-income learners. Indeed, an analysis of the DBE's EMIS data confirms this, as shown in Table 2.

Table 2: Racial composition of independent and public schools, 2012

\begin{tabular}{|l|l|l|l|l|l|l|}
\hline & Black & Coloured & Indian & White & Other & Total \\
\hline Independent & 291903 & 24805 & 33317 & 113860 & 6156 & 470041 \\
\hline Public & 10147680 & 956824 & 174326 & 507262 & 24143 & 11810235 \\
\hline Total & 10439583 & 981629 & 207643 & 621122 & 30299 & 12280276 \\
\hline Independent & $62.1 \%$ & $5.3 \%$ & $7.1 \%$ & $24.2 \%$ & $1.3 \%$ & $100 \%$ \\
\hline Public & $85.9 \%$ & $8.1 \%$ & $1.5 \%$ & $4.3 \%$ & $0.2 \%$ & $100 \%$ \\
\hline Total & $85.0 \%$ & $8.0 \%$ & $1.7 \%$ & $5.1 \%$ & $0.2 \%$ & $100 \%$ \\
\hline
\end{tabular}

According to official statistics there were 1681 registered independent schools in South Africa in 2014 with 538421 learners. Draper and Hofmeyr (2015:11) optimistically estimate that the true number of independent schools is probably much higher, at around 3500, as an unknown number of schools are unregistered and thus not counted in official statistics. However, this seems to be an over-estimate, considering that another Centre for Development and Enterprise (CDE) study found that less than a quarter of independent schools in operation in six poor areas were not registered (Schirmer, Johnston and Bernstein, 2010:6). The CDE estimates that in 2014 around 250000 learners were enrolled in low-fee independent schools charging less than R12 000 per year (Draper and Hofmeyr, 2015:16). As will be shown later, a combination of regulation and limited state subsidisation makes it relatively unattractive for most parents in low income communities to choose to send their children to low fee independent schools, so this estimate too may be on the high side.

The CDE's 2010 survey of schools in six poor areas in three provinces (Gauteng, Limpopo and the Eastern Cape) sheds light on some characteristics of low-fee private schools in the country. Private schools had 
smaller classes than public schools, but also had fewer facilities. They were located in a wide range of buildings, from abandoned factories and shacks to shopping centres. As in other countries, independent school teachers were paid much less than government teachers and had lower qualification levels. Nonetheless, private schools had much lower levels of teacher absenteeism (Schirmer, Johnston and Bernstein, 2010:6, 48).

In 2014 registered private schools made up 6.5 percent of all South African schools, making South Africa's private school sector small relative to those in many other developing countries. Moreover, South Africa's private schools differ from those in other developing countries in that most low-fee South African private schools are not-for-profit and have substantially higher fees, and the majority of students are girls. The South African sector is also relatively highly regulated, but benefits from subsidisation, which is fairly uncommon in developing countries (Draper and Hofmeyr, 2015:10).

There is very limited evidence on the performance of South African private schools. As part of the CDE's survey of independent schools, a sample of Grade 6 private school learners were given achievement tests. The CDE found mixed evidence when comparing the achievement of private school learners to public school learners from the same area. In some areas private school students performed better, while in others government school learners had the advantage. However, the authors note that the test data for public school learners was potentially untrustworthy, and thus compare private school achievement with government school achievement in the National Systemic Evaluation of 2005 (three years prior to the survey). Using this data the achievement of private school students was 12 percent higher than government school students. A comparison of 2008 matric results for the sample of private schools and government schools in the same areas also suggests a private school advantage. 24 percent of learners at registered private schools received more than 60 percent in mathematics, compared to 10 percent at public schools that were not former Model C schools. The differences in results were similar for other subjects (Schirmer, Johnston and Bernstein, 2010:36-7). However, the present study is the first multivariate analysis which controls for differences in the resources available to government and independent schools in South Africa.

Despite the rapid growth of independent schools in South Africa, there are concerns over their affordability for the poorest in South Africa. Low-fee schools in South Africa charge significantly higher fees than schools considered low-fee in other developing countries - in India low-fee private schools charge below R2000 per year, while in Kenya some low-fee schools charge as little as R360 a year. This may be because the costs facing private schools in South Africa are fairly high relative to other developing countries, which Draper and Hofmeyr (2015:11) ascribe inter alia to the sector being more regulated and thus having higher compliance costs, raising the relative cost particularly for low-fee schools (Draper and Hofmeyr, 2015:11). Thus while low-fee independent schools in South Africa are much more affordable than pricier schools, they remain unaffordable for the very poor (Hofmeyr et al., 2013:3, 10). It is said that low-fee private schools mainly serve the children of those who live in less affluent areas but have jobs, such as police officials and public school teachers (Schirmer, Johnston and Bernstein, 2010:39). This naturally places a limit on the growth of such schools. 


\subsection{Subsidisation}

Average subsidies to public schools amounted to almost R12 000 in 2014. In accordance with the South African Schools Act of 1996, as amended, independent schools charging fees below around $2 \frac{1}{2}$ times the average in a province (around R30 000 per year if the average fee is taken to be R12 000 in 2014) are eligible for a per-learner government subsidy. In practice, however, independent schools in most provinces do not receive the subsidies that they are eligible for. Schools charging less than half the average public subsidy (roughly R6 000 per year in 2014) are eligible for a subsidy amounting to 60 percent of the provincial average estimate of expenditure per learner in government schools, i.e. R7 200, leaving some with net resources that could slightly exceed the amount available to no fee public schools, i.e. R13 200 as against R12 000 . Schools charging less than R12 000 may receive a 40 percent subsidy, R4 800, so that their actual resources could reach almost as high as R16 800. Schools with fees between R12 000 and R18 000, and those between R18 000 and R30 000, can obtain a 25 percent and 15 percent subsidy, respectively. Figure 1 shows the resources per child (subsidies paid by government as well as school fees) of independent schools over a range of school fees. These should be compared to the resources of public schools, which are for no-fee public schools simply R12 000 (assuming this to be the average amount), whilst for fee-paying public schools the amount would be R12 000 plus the value of the fee per child. It can be seen that across the range of fees, the resources available for public schools charging the same fees as their private school counterparts would be considerable more; from R30 000 fees and higher, this difference would amount to R12 000, i.e. the full extent of the public subsidy. At lower fees, of course, the difference is smaller. Looked at alternatively, from a school fee of R12 000 or more, private schools would have more resources than public schools.

Figure 1: Resources available per child in no fee schools, subsidised independent schools, fee-paying public schools and unsubsidised independent schools (fees only)

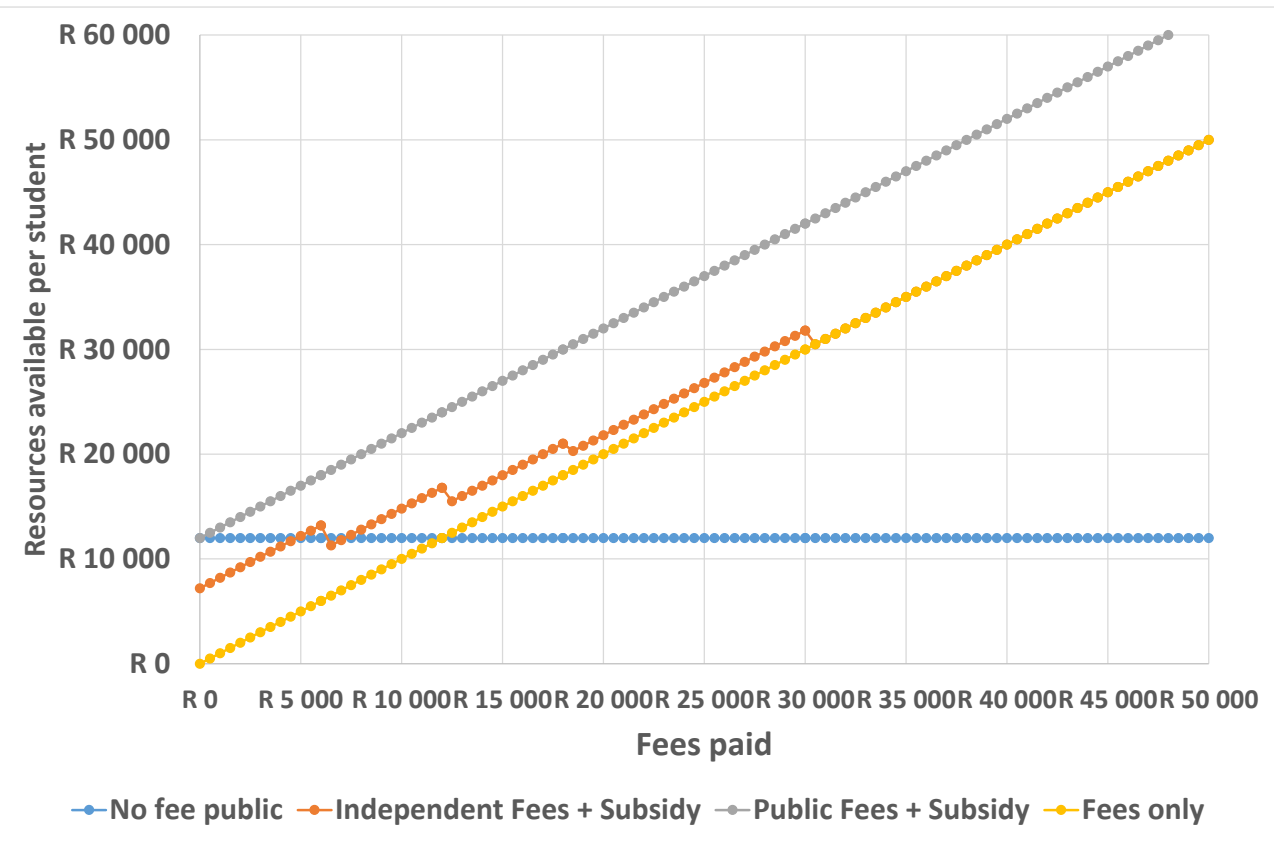

Source: Own calculations based on the subsidy formula set out in the SA Schools Act and assuming a public school subsidy per child of R12 000. Note that the horizontal line for the no fee public schools was added to show the level of public school subsidies; even though it is shown as if it applies at different school fee levels, though by definition such schools may not charge fees. 
The CDE regards schools charging below R12 000 as low-fee schools and those charging between R12 000 and R30 000 as mid-fee schools (Draper and Hofmeyr, 2015:13), though it may be argued that in the context of a middle income developing country these are somewhat high fees to justify those categorisations. Figure 2 shows the resources available per child in private schools expressed as a percentage of those in public schools if R12 000 is used as the value of the public school subsidy per child. Here, three cases can be distinguished:

- Relative to no fee public schools, registered private schools with fees of R4 800 or more who receive the appropriate subsidy have more resources in terms of school fees plus public subsidies (the top line). (For this line, the fees paid refer only to the private school fees, as such public schools have no fees.)

- As can be seen, the proportion of public school resources available per child in private schools initially peeks at a school fees of R6 000, where after the fall in the public subsidy percentage at various thresholds has a downward effect on this percentage until school fees rise beyond R20 000. (Shown in the line second from the top)

- For unregistered independent schools, school resources per child remain below $60 \%$ of those in public schools charging the same fees until fees reach a level of R20 000 (bottom line of the graph). For fees of R12 000 or less, resources in public schools with similar fees are at least twice the resources available to private schools. For such private schools to survive would require that teachers be paid half or less than half of what teachers earn in public schools. If in addition the independent schools have smaller class sizes, this would mean that such schools would have even less than half the financial resources per child available than is the case in no fee public schools. (It is perhaps possible that a greater teaching load per teachers may reduce this deficit somewhat, but this can only happen to a limited extent). Considering that teacher costs constitute close to $90 \%$ of the aggregate recurrent costs in public schools, this would require that such schools pay teachers less than half what they could earn in public schools, while there is a shortage of qualified teachers in many parts of the country. For very low fees school, e.g. with school fees of only R6000 per child, the resources available per child would be one third or even less of what is available in public schools charging similar fees. In a labour market where most qualified teachers do get a job, this must mean that such schools would largely have to draw on unqualified teachers. In that respect, for such low fees this could not be all that different from the situation in India, as described above. Also, from the perspective of parents, it would make little sense to send their children to schools that would costs them much more than public schools, even many fee-paying public schools, if they would simply get unqualified teachers. They are then likely to rather attend fee paying public schools, where these are available. 
Figure 2: Resources available per student in independent schools as percentage of resources in public schools

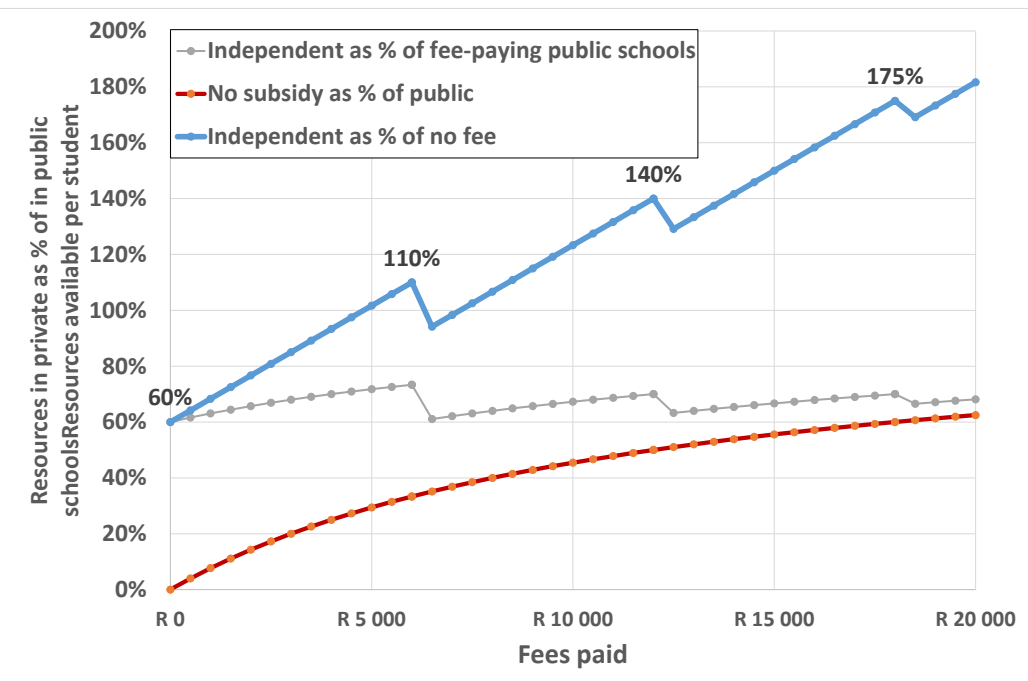

So unregistered, or unsubsidised (because of provincial failure to pay subsidies) schools are unlikely to be a major growth area, unless these unqualified teachers can do a much better job of teaching than is found in public schools, including low-fee public schools. The more likely growth area would be the registered independent schools, where growth is limited by the failure of some provinces to pay the subsidies that they are legislatively obligated to pay.

To qualify for a subsidy, independent schools must attain certain minimum standards. Their average student performance in the Annual National Assessments and matric examinations must be equal to or better than the provincial average, or else schools could lose their subsidy for the subsequent year. Furthermore, independent schools are required to comply with a management checklist and to have audited financial statements in order to receive a subsidy. Independent schools may also have their accreditation refused or be deregistered if they fail to follow regulations and to attain sufficient standards for teachers and facilities. The requirements imposed on independent schools are thus much more stringent than those for government schools (Draper and Hofmeyr, 2015:14, Hofmeyr et al., 2013:15).

\subsection{Regulating and monitoring independent schools}

When assessing the contribution of the regulatory environment of independent schools it is important to consider it as part of the wider institutional framework and specifically, a range of potential oversight mechanisms.

A school has at least four potential stakeholders that could fulfil an oversight role: firstly, the clients, which in this case are the parents because the children are minors; secondly, the funder, who would be a combination of government and the parents; thirdly, the regulator; and lastly, the owner. In the case of government schools the government would represent both the owner and the regulator. In the case of independent schools, there are two potential regulators: government and peer oversight bodies. Also, for the independent sector the organisational form may differ based on whether the owner is profit-seeking 
or not profit-seeking and this will also influence the oversight and incentives provided to teachers and other staff members.

Each of these stakeholders have their own weaknesses and blinds spots and therefore an ideal oversight framework is one where all stakeholders are present, have the right information to assess the performance of the school based on their perspective and interests and have mechanisms whereby they can reward the school for good performance or punish the school for poor performance to ensure that their assessment of the school performance counts. Unfortunately, this is often not the case.

For instance, the literature shows that the ability of parents to monitor their child's schooling and the performance of the school is widely varied and correlated with parental education. In South Africa, many parents of current learners have never attended a good school and hence have no frame of reference for what can be expected of a school. Furthermore, low self-esteem and social status can inhibit parents from speaking up or taking actions about their concerns. Due to the correlation with social status and education of the parents, one would therefore expect parental monitoring to be significantly worse in poor communities, which can be a channel for perpetuating low quality of education. Teachers teaching in poor communities may find it easier to underperform and not be called to account than teachers at middle class or affluent schools.

While there is a notoriously large degree of variation in the performance of government schools - due partly to differences in fee contributions and parental involvement and monitoring - the variation in performance would be presumed to be far greater in the independent sector for at least two reasons. Firstly, because the independent sector is more fragmented and individual than the government system; and secondly, because the most informal and low-cost independent sector schools are subject to minimal scrutiny because they would often not have the bureaucracy in place to be part of the government's monitoring framework and would not be able to afford to join the independent sector's peer oversight bodies, or have little incentive to do so. Such schools will remain a worry as long as these regulatory loopholes exist. Little information exists about such schools and that is a part of the problem.

If such schools are for-profit organisations that serve parents who understand the value of education and are willing to make substantial personal sacrifices to buy such an education for their children, but have little basis to choose a good school due to their own lack of exposure to quality schooling, then such loopholes may be even more worrying. This is a segment of the independent school sector that requires more research and more regulation. Anecdotal evidence in news media reports children having to rise daily at 4 am or 5 am to take a bus or a train to a better school far away from the poor community where they live. Such transport costs would often represent a significant additional burden to the family - and if they are attending an independent school, the fees would impose a further financial burden. From a public policy perspective it is vital to provide more information on the quality of schools to guide parents in their choices so as to ensure that these household sacrifices are not made in vain.

On the other hand, there are concerns about both the efficacy of independent school regulation and the burden imposed by the current regulation. Independent schools subjected to government regulation complain about the frequent reporting, various quality assurance processes and numerous compliance requirements and argue that such demands could be counterproductive, excluding smaller schools that need the subsidy more badly. To operate as a registered independent school and receive a state subsidy, 
a school must successfully navigate three application processes, each with their own set of requirements, each differing across provinces.

Firstly, an independent school is required to register with the department of education in the province in which it is situated. Even though this occurs within common national legislation, the National Schools Act, each province lays down their own conditions of registration and implements these regulations with varying levels of intensity, but commonly an application for registration is made to the Head of Department of the appropriate province, accompanied by a long list of supporting documentation. ${ }^{1}$ The legislation in both the Western Cape and Gauteng has clear time lines defined for the approval of the registration of an independent school, and in both these provinces the application for registration of an independent school is said to be approved within 3 months from the date of receipt of application. This, however, is not the case in all provinces, with the KwaZulu-Natal legislation for example, not mentioning any commitments from government's side to timeously consider the application for registration of an independent school. Regardless of the province in which an application has been made, the perception is that the extensive application process for registration has often caused unreasonably long delays in obtaining registration (Centre for Development and Enterprise, 2010). Once the application for registration has been approved, a school will be granted an Educational Management Information Systems (EMIS) number as proof of registration.

Secondly, in order to receive a state subsidy, not-for-profit schools have to go through another application process, once they are registered with the province and has been operational for at least one full academic year. A state subsidy can range from 15 to 60 per cent of the average cost per child in an ordinary public school in the relevant province, and is dependent on the school meeting a set of requirements as determined by provincial minister. These requirements vary by province, and proving compliance to these requirements can become quite burdensome in some provinces.

Finally, all independent schools also need to be registered with the quality assurance council, Umalusi. This requirement has come into effect in 2008 through the General and Further Education and Training Quality Assurance (GEFTQA) Amendment Act and states that a school is not operating legally if not accredited or seeking accreditation from Umalusi. Umalusi, however, has been slow in implementing the accreditation process, which has led to further delays in the registration of independent schools.

The varying capacity within provincial departments means that the regulations and processes have been implemented with different degrees of intensity and efficacy. Inefficiencies at the provincial level have often resulted in schools struggling to register, and in subsidies not being provided, being paid late, or being cut without any communication from the provincial department. These factors create a disabling environment by undermining the rights of independent schools to their state benefits and thereby

\footnotetext{
${ }^{1}$ The list includes: 1) The constitution of the school covering all matters relating to the control of the school, including ownership, character, aims, governance, funding and the language and admission policy; 2) A floor and site plan, as well as details of the facilities for the implementation of the curriculum, as well as for co-curricular and extra-curricular activities; 3 ) Details of the facilities which will be made available to serve the needs of learners with disabilities; 4) A certified copy of a valid certificate of occupancy; 5) A certified copy of a valid certificate from the relevant health authorities confirming that the proposed facilities at the independent school will meet the minimum health and safety requirements; 6 ) A certified copy of a valid certificate from the relevant municipality confirming that the proposed facilities will meet the requirements of the municipal by laws; 7) A proposed list of educators with their qualifications and their South African Council for Educators (SACE) registration numbers; 8) Proof that the school will be financially viable for at least 12 months after registration.
} 
endangering the existence of low fee independent schools (Hofmeyer, et al., 2013). The poor regulations, however, also allow for some independent schools to escape detection and remain unregistered. These schools, however, will not be eligible for a state subsidy.

The research team's efforts in obtaining data from the various departments of education has been instructive regarding the capacity of the various directorates of independent schools across provinces. In the Gauteng Department of Education it was nearly impossible to make an appointment with the Director of Independent Schools, and conversations with various officials in the Independent Schools directorate seemed to indicate that no electronic database of all registered independent schools existed and that all the information was only available on the application forms submitted by the various schools. However, the Research Co-ordination Unit managed to provide the team with all the necessary information within minutes. In KwaZulu-Natal, too, it proved to be nearly impossible to make contact with the Director of Independent Schools or with any of the officials in the Directorate.

The problems encountered in attempting to access data from these government divisions cast doubt on government's understanding that the private sector can be an important ally. While the independent sector is currently small, it has been expanding and the problems relating to poor government regulation are therefore set to increase in scale and seriousness. With high unemployment levels, it is worrying that there are relatively few entry barriers and few punitive measures to prevent profit-seeking entrepreneurs and extorting money from well-meaning but uneducated and vulnerable parents who are eager to provide a bright future for their children. 


\subsection{Data}

This study set out to use mainly existing data sources and concentrate on a comparison of public schools and registered independent schools in the Western Cape and Gauteng, but eventually the analysis was also extended beyond this to the national level. Also, the initial intention was to focus on primary schools only, where larger numbers make it possible to obtain better estimates of the possible statistical relationship between school type and performance, but the availability of secondary school data at the national level was also used to extend the analysis to secondary schools. Existing data on registered independent schools is sparse and uneven across provinces. This provides further motivation for concentrating on the Western Cape and Gauteng. The interest is in the schools attended by poorer children, i.e. independent schools that would be affordable to households in poor communities.

The Annual National Assessments of 2012 were used to measure school performance, with the focus on Grade 6 Mathematics in primary schools, and Grade 9 Mathematics in secondary schools. Using Home Language rather than Mathematics gave similar results but a poorer fit in the regression analyses, indicating that there is more noise in this data, a result that echoes previous analyses. In the Western Cape, permission was also obtained to use the Systemic School Evaluations carried out in this province only (independent schools have only recently started participating in these tests), but these are closely correlated to the ANA results (Van der Berg, 2015) and data analysis showed it did not offer any different insights that warranted treating the Western Cape differently from other provinces; also, the small sample size of independent schools in this data set limited its usefulness. Similarly, matric results were also used as outcome variable at secondary school, but again did not give a clearer picture and the fact that many children drop out before matric means that an important part of school performance is then ignored.

The WCED also agreed to provide their database on fees paid by independent schools (as this is used for determining subsidies to low fee independent schools, it is likely that some of the data would underreport the effective costs to parents of their children attending such schools). Much time was spent trying to obtain further data on fees of independent schools (see the section on regulation above), with limited success, though the Gauteng school fee data could eventually be obtained. For both independent and public schools, the school fee data obtained from the national DBE system was of poor quality, and much work had to go into cleaning and verifying this data, though even after that some uncertainty remained. For instance, where official school fee data for different years fluctuated greatly, decisions had to be taken on what values to use that were more credible, and inflation adjustments had to be made across years where data was missing for 2014, the year for which most school fee data could be obtained. The Western Cape school fee data appears to be the most accurate of those the team could obtain, followed by that for Gauteng.

Data on aggregate school resources, or costs, was obtained from adding the subsidies per child obtained from the provincial departments to the fees obtained from parents that were discussed above. The provincial data on the subsidy per child in public schools that could be obtained was that in Table 3 . 
Table 3: Subsidies per learner in ordinary public schools

\begin{tabular}{|l|l|l|l|l|}
\hline & \multicolumn{2}{|l|}{$\begin{array}{l}\text { Calculated from } \\
\text { 2012/14 }\end{array}$} & audited figures & \multicolumn{2}{l|}{ Inflation adjustment to 2014} \\
\hline & Primary schools & Secondary schools & Primary schools & Secondary schools \\
\hline Western Cape & R11 292 & R12 003 & R 11 939 & R 12 691 \\
\hline Gauteng & R10 657 & R12 072 & R 11 268 & R 12 764 \\
\hline Eastern Cape & R5 971 & R23 146 & R 12 513 & R 12 200 \\
\hline Free State & R12 534 & R13 202 & R13 252 & R 13 957 \\
\hline Kwazulu-Natal & R11 419 & R10 985 & R12 073 & R 11 615 \\
\hline Limpopo & R11 122 & R12 534 & R11 759 & R 13 252 \\
\hline Mpumalanga & R12 625 & R10 840 & R13 348 & R 11 451 \\
\hline Northern Cape & R12 938 & R10 758 & R13 679 & R 11 374 \\
\hline Northwest & R12 090 & R9 915 & R12 783 & R 10 483 \\
\hline
\end{tabular}

Note: The obvious discrepancy in the Eastern Cape is probably based on an inaccurate allocation between primary and secondary schools and expenditures. Thus the average national figures were used for that province in 2014 in the data.

Subsidies for independent schools in the data were calculated using the formula based on the SA Schools Act that was discussed earlier to the public school subsidy levels in the table. The assumption had to be made that these subsidies are actually paid, something that apparently is fairly certain in the two provinces studied, but not in others. Thus it is not surprising that the results for the national datasets provided less statistically significant coefficients, as will be seen later.

Figures $3 \mathrm{a}$ to $3 \mathrm{~h}$ show the kernel density distributions of the average mathematics scores in Grade 6 or 9 for public and independent schools. In each of the four data samples (Western Cape primary, Gauteng primary, SA primary and SA secondary), a graph of the full sample is shown first, i.e. including schools in the top decile of the distribution of school fees in that sample, and next to it a graph containing only deciles 8 and 9 for the sample in question. Kernel densities are in essence similar to smoothed histograms, thus making interpretation of the vertical axis difficult, but they allow better comparison for two or more sub-samples than do histograms. The important thing to focus on is where the bulk of the distribution lies, with the mode (the top point in the graph) of particular interest.

Before controlling for school fees, i.e. for the full samples, it is to be expected that independent schools would fare better, as a greater proportion of their learners would be likely to be from higher socioeconomic backgrounds. However, when confining the analysis to particular deciles (as in all the graphs on the right), some of the heterogeneity in socio-economic background is reduced, so it is less clear whether private or public schools would perform best. In all but one of the graphs, the mode for independent schools lies to the right of that for public schools, indicating that in most cases independent schools performed better than public schools in the ANA Mathematics tests. The exception is for quintile 8 and 9 in the Western Cape, where the relatively small number of independent schools captured in the data performed worse than the public schools in the same school fee deciles. The regression analysis in the next section will confirm that the Western Cape is an outlier in terms of the relative performance of public schools. 
Figure 3: Distribution of ANA Mathematics scores for public and independent school, all schools and quintile 8 and 9 schools only, 2012
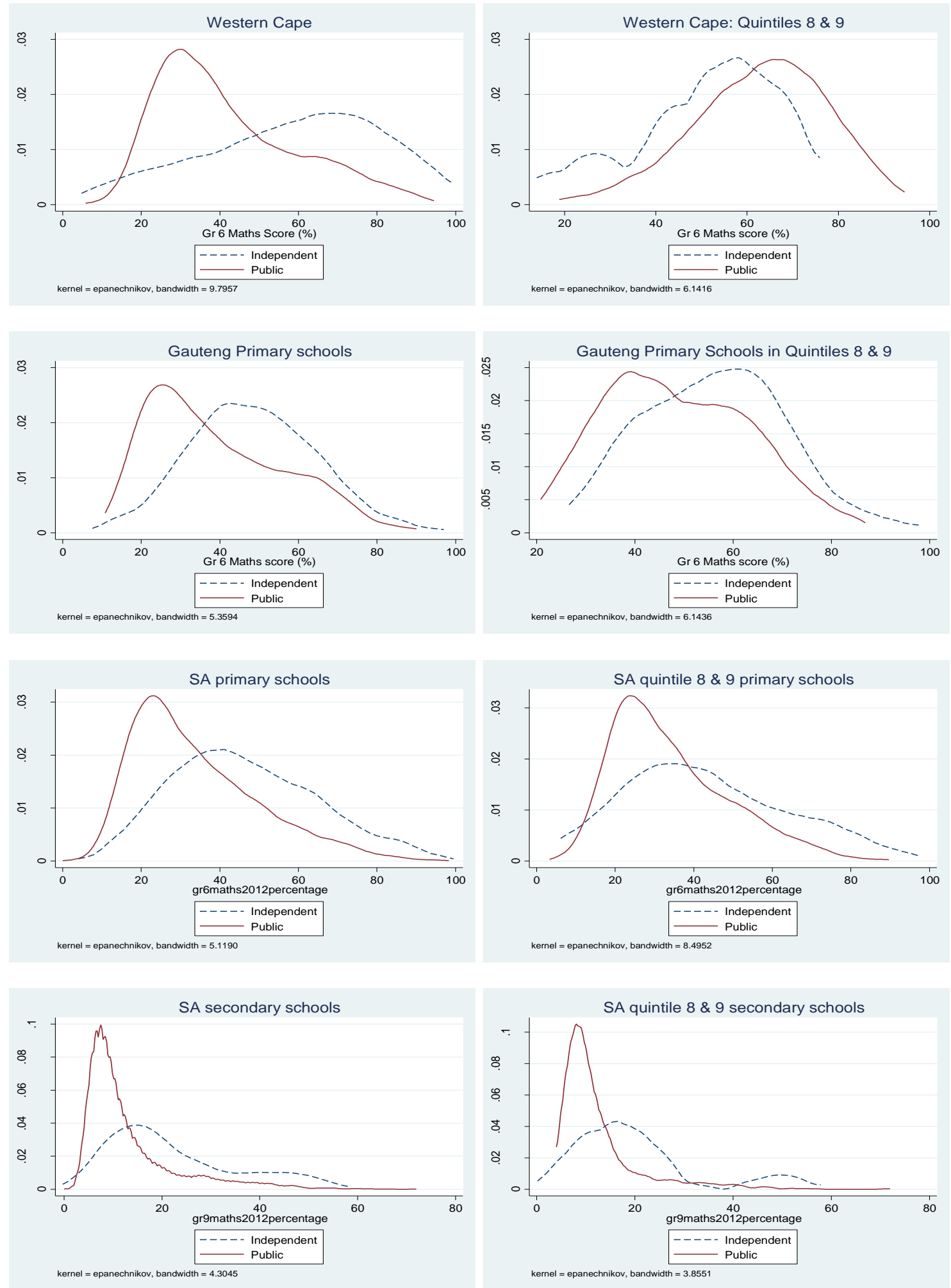


\subsection{Methodology}

The intention with the analysis was to investigate how the performance of public schools and independent schools in the same fee bracket compare (i.e. relevant from the view point of the parents wanting to make an investment in their child's education). For this purpose the study uses education production functions (multivariate regressions) to estimate to what extent available resource constraints and socio-economic factors may explain possible differences in performance between these two groups of schools. As the full data set also includes schools that are clearly not low fee, the analysis is initially run for a full model in each of the four sets of estimates that are attempted: For Western Cape primary schools, Gauteng primary schools, South African primary schools and then also South African secondary schools (sample size prevented an analysis of secondary schools at provincial level).

Once the data had been obtained, descriptive analyses were first undertaken. Because of uncertainty about the school fee data in particular, it was decided, in line with the initial outline for this study, to concentrate the analysis on the Western Cape and to a lesser extent Gauteng, and then to do some initial work on the national data to see whether it could add to understanding. The data analysis was made more difficult by the fact that only a small sample of independent schools both did have school fee data that could be used and participated in the cognitive tests that were used as outcome measures. Furthermore, because not all provinces pay the subsidies to independent schools that they quality for, the overall resources (school fees plus public subsidy) per school that were calculated based on the assumed subsidies may not be accurate for schools outside of the Western Cape and Gauteng.

The nature of the data limitations to obtain good estimates of the association between fees or costs and school performance for low fee schools can perhaps be best appreciated by the following table, setting out the number of independent schools in each decile of the distribution of school fees and the number of such schools for which ANA (performance) data are also available. Note the very small number of registered independent schools in the Western Cape that were not amongst the more expensive schools (the top decile of schools by school fees).

The data limitations can be gauged from the fact that, outside of the top decile of schools by school fee in each of the samples, there are only 11 primary independent schools in the Western Cape with ANA data, 120 in Gauteng, and 41 in the South African primary sample (note that the deciles are calculated for each sample separately). For the national secondary school sample, only 25 independent schools could be used outside of the top decile.

The regression models were run with only two other control variables, enrolment and whether the school is located in an urban area. In themselves, these control variables are not of interest but they were purely added to reduce what may have been spurious correlation due to these variables being left out. The functional form for both the school fees and the resources ("costs", i.e. fees plus subsidies) that gave the best fit were found to be obtained with a log form and a square of the log of the variable. Although the impact of school fees and resources is of interest, the main interest here is the direction and the statistical significance of the dummy for a school being independent. This will be discussed in the next section. 
Table 4: Registered independent schools in the Western Cape by school fee decile and participation in ANA, 2014

\begin{tabular}{|c|c|c|c|c|}
\hline & $\begin{array}{l}\text { Minimum } \\
\text { school fees }\end{array}$ & Public schools & $\begin{array}{l}\text { Independent } \\
\text { schools }\end{array}$ & $\begin{array}{l}\text { Independent } \\
\text { schools that } \\
\text { participated in ANA }\end{array}$ \\
\hline \multicolumn{5}{|c|}{ Western Cape } \\
\hline Deciles 1 to 4 & RO & 544 & 0 & 0 \\
\hline Decile 5 & R15 & 105 & 2 & 1 \\
\hline Decile 6 & R266 & 119 & 1 & 0 \\
\hline Decile 7 & R440 & 122 & 7 & 1 \\
\hline Decile 8 & R1 464 & 108 & 25 & 7 \\
\hline Decile 9 & R6 090 & 97 & 27 & 2 \\
\hline Decile 10 & R13 500 & 27 & 101 & 20 \\
\hline Total & & 1122 & 163 & 31 \\
\hline \multicolumn{5}{|c|}{ Gauteng } \\
\hline Deciles 1 to 4 & Ro & 768 & 0 & 0 \\
\hline Decile 5 & R9 & 137 & 28 & 10 \\
\hline Decile 6 & R1 208 & 132 & 51 & 15 \\
\hline Decile 7 & R4560 & 67 & 119 & 58 \\
\hline Decile 8 & R14 860 & 85 & 101 & 30 \\
\hline Decile 9 & R35 742 & 114 & 72 & 7 \\
\hline Decile 10 & R28 489 & 125 & 60 & 4 \\
\hline Total & & 1428 & 431 & 124 \\
\hline \multicolumn{5}{|c|}{ National primary } \\
\hline Deciles 1 to 7 & RO & 14838 & 2 & 1 \\
\hline Decile 8 & R15 & 332 & 8 & 2 \\
\hline Decile 9 & R301 & 1784 & 114 & 38 \\
\hline Decile 10 & R5497 & 1153 & 744 & 262 \\
\hline Total & & 18107 & 868 & 303 \\
\hline \multicolumn{5}{|c|}{ National secondary } \\
\hline Deciles 1 to 7 & Ro & 8079 & 0 & 0 \\
\hline Decile 8 & R15 & 288 & 21 & 2 \\
\hline Decile 9 & R650 & 830 & 216 & 23 \\
\hline Decile 10 & R11 500 & 493 & 555 & 98 \\
\hline Total & & 9690 & 792 & 123 \\
\hline
\end{tabular}




\section{EMPIRICAL FINDINGS}

\subsection{Introduction to the empirical findings}

The poor quality of the data limits the confidence that one could have in the results, even beyond the normal testing of statistical confidence that such regressions analyses habitually report. Also, statistical significance is limited by the small sample size, particularly of low fee independent schools, which are the central focus of this report, and by a lot of heterogeneity in performance. As indicated, this small sample size is the result of limited numbers of registered independent schools, the lack of school fee and ANA data for these schools, and the small number of them that charge low fees.

Despite these limitations, the statistical results are not completely disappointing. Regressions results are shown in Appendix Table 1, with the dependent variable being the average performance in the 2014 ANA in Grade 6 Mathematics for primary schools, and for secondary schools the performance in the Grade 9 ANA. The results are presented for three geographic areas, the Western Cape, Gauteng, and all of South Africa, in declining order of the accuracy of the school fee data. For the two provinces concerned, the number of observations available for secondary schools did not allow for an analysis at secondary school level, so secondary school results are only shown for all of South Africa. However, as indicated, if some provinces do not pay the subsidies to independent schools, the national data may be less accurate, as it had to be assumed that all schools are subsidised according to the official formula.

Two sets of results are generated, one to determine the association between school fees and performance (the top half of the page), the other that between financial resources available per child (school fees plus subsidies) and school performance (the bottom half). The models are in each case first run for all schools, then the richest decile of schools (judged by school fees) are dropped, and subsequently also the second richest decile. Ideally rich schools should not have been considered at all, but in order to have more stable estimates, it is not always sensible to only consider model results for low fee schools. In all models, controls for whether the school is urban or not, and for enrolment are added.

Finally, when considering the results presented below, it is imperative to consider that these results do not show causal effects. The reason, as discussed in the early parts of this report, is that it is simply uncertain to what extent the selection of students into independent schools is non-random in terms of their ability, socio-economic background and motivation, and parental effort to support them. That being the case, it may well be that students performing better in independent schools than in public schools may not be the results of the schools, but of the selection process. It is not possible with the available data to set up a counter-factual of how the same students would have performed in the other part of the system, thus the causal effects of the schools cannot be determined.

\subsection{Findings related to resources (school fees plus subsidies)}

The results for resources ('costs"), in the bottom panel of Appendix Table 1, are discussed first. The provincial models generally fit better than the national ones, with R-squares ranging from 0.12 to 0.48 . For both Gauteng and the Western Cape, the dummy for independent schools is positive and statistically significant in all three models, and this also applies for two of the models for primary schools at a national 
level, though the third, which considers lower fee schools, has a dummy that is large, significant and negative. At secondary level there is no significant statistical evidence either way.

Thus the provincial results show that in the Western Cape and Gauteng, independent schools perform better with the same - public plus private - financial resources than public schools, or put differently, they require fewer resources to obtain similar results. This can be summarised as "independent schools use resources more efficiently", but only the affluent ones amongst them have similar resources as fee-paying public schools, given how the public subsidies for independent schools function. If actual public subsidies of independent schools are smaller than indicated, this would further strengthen this finding.

\subsection{Findings related to school fees}

In primary schools in the Western Cape, the regression results indicate that independent schools do not perform as well as public schools that charge the same school fees. The independent school dummy is negative in all three and significant in two of the three the models for the Western Cape, indicating that this finding holds if we consider all schools in the province, but also when the model is run without the highest costs schools; the result loses its significance if the top two deciles are excluded, perhaps in part because of the small independent school sample that then remains. Thus independent schools in the Western Cape that they do not consistently provide as good results in ANA Maths Gr6 as public schools charging the same school fees, consistent with Figure $3 \mathrm{~b}$ discussed before - this can be summarised as "In the Western Cape, independent schools do not bring parents value for money". However, when the analysis excludes affluent (Quintile 10) schools, this result does not consistently hold. The high R-squared in the Western Cape indicates that there is a relatively strong relationship between performance and fees, in particular though the other regressors also play a role.

It is instructive to see, though, that the sign of the relationship turns around for all three the Gauteng primary school models, and that this relationship is significant in all cases, with both the magnitude of the effect and the strength of the relationship rising as more schools at the top end are excluded. It appears to show strong evidence that lower fee independent schools in Gauteng provide better results than public schools charging similar fees. This indeed implies that "In Gauteng, independent schools provide parents with better value for money", even despite the fact that the resources at their disposal are less than those in public schools, due to the reduced subsidies.

At a national level, the results are less clear, be it at primary or secondary level. Only in the case of the full national primary sample is the dummy for independent schools significant, and in that case, the sign is negative, as in the Western Cape. But the sign changes around much and the results lose significance in the reduced sample models. At the secondary level too, the signs are inconsistent and the results insignificant. The last five models shown all have exceedingly low R-squares, indicating that much of the variation in performance cannot be explained by the models. 


\section{SUMMARY AND CONCLUSIONS}

This study has set out to determine whether independent schools perform better than public schools with similar fees, or public schools with similar resources.

For school fees, the findings are mixed: In Western Cape, in all three models, independent schools do not perform as well as public schools with similar school fees, i.e. parents do not get as much value for money in independent as in public schools. This finding also holds for the national sample of primary schools, but is only significant for the full sample. In contrast, in Gauteng all three models show a positive effect on performance of being in independent schools relative to public ones, i.e. parents do get value for money considering the school fees they pay.

Regarding the performance relative to the resource used, the results are more unanimous: Independent schools use resources better, in terms of achieving higher performance with similar resources, or put differently, requiring fewer resources to achieve similar results as public schools.

The results obtained show that independent schools do use resources more sparingly than public schools, even though they may not always bring parents value for money. From the perspective of society, if the results found here would also have held if there was no selection effect (i.e. if they are interpreted causally), they can be considered as saving the state money to achieve the same level of cognitive outcomes, or alternatively, achieving higher cognitive outcomes with similar resources (both subsidies and fees).

Also, if the results are interpreted as at least in part causal, they are likely to stem from the organisational aspects. As indicated in the introduction to this report, economic and organisational theory suggests that the advantage of independent schools may relate to teacher and principals motivation, or that accountability relationships between parents and school staff are simpler and therefore more easily aligned in such schools. Organisational theory also suggests that greater organisational independence may promote customisation, client responsiveness and innovation and should help to facilitate tighter feedback and learning loops.

An analysis of the fees and resources of the different school types (no fee public, fee-paying public, registered and subsidy-receiving independent schools, and unsubsidised, usually unregister independent schools) gives some interesting pointers to the likely growth of the independent school sector. It is likely that unregistered independent schools will remain relatively small in number, as the resources they can gain from school fees alone are relatively insubstantial, thus they will remain compelled to pay teachers far less, and therefore largely having to appoint unqualified teachers, often on short term contracts. That is also likely to undermine their performance and thus their attractiveness to parents. Registered public schools, on the other hand, may show more growth, particularly as disillusion with the quality of public schooling rises. However, if provinces avoid their obligation to pay subsidies to such school and continue to place obstacles in the way of schools attempting to register, their growth may be stifled. Also, the subsidy formula is not very supportive of the growth of such independent schools in competition with public ones that get far more state subsidies, but at least the availability of such subsidies in South Africa is a positive factor that has had an important influence on the growth of the independent school sector. However, given the limited information available to parents and the fact that many parents are poorly 
equipped to judge the quality of schooling their children receive, proper regulation of the sector is needed, but should not create bureaucratic obstacles.

Considering the limited causal inferences that can be drawn from a study of this nature, it is pertinent also to consider what further research may be necessary to get a better understanding of both the impact of independent schools and the reasons for that impact. This will require a much larger study, including additional data gathering (e.g. own testing of pupils, testing of teachers, information on recruitment and management of teachers, number of teachers, management, classroom practices). This will increase both the cost and the duration of such a project. Specifically, it would be important to investigate where the independent school advantage originates, i.e. what role does management, more teacher motivation or teacher knowledge play? Further analysis could also provide leverage for influencing government policy making - both in terms of identifying bottlenecks and weaknesses in the public school sector and also in proposing more support and scope for making a growing independent school sector. 


\section{REFERENCES}

Akaguri, L. 2011. Quality low-fee private schools for the rural poor: perception or reality? Evidence from southern Ghana. CREATE Pathways to Access Research Monograph No. 69.

Akaguri, L. 2014. Fee-free public or low-fee private basic education in rural Ghana: how does the cost influence the choice of the poor? Compare: A Journal of Comparative and International Education, 44(2): 140-161.

Altonji, J. G., Elder, T. E. \& Taber, C. R. 2005. Selection on observed and unobserved variables: assessing the effectiveness of Catholic schools. Journal of Political Economy, 113(1): 151-184.

Andrabi, T., Das, J. \& Khwaja, A. I. 2008. A dime a day: the possibilities and limits of private schooling in Pakistan. Comparative Education Review, 52(3): 329-355.

Andrabi, T., Das, J., Khwaja, A. I. \& Zajonc, T. 2011. Do value-added estimates add value? Accounting for learning dynamics. American Economic Journal: Applied Economics, 3(3): 29-54.

Angrist, J., Bettinger, E. \& Kremer, M. 2006. Long-term educational consequences of secondary school vouchers: evidence from administrative records in Colombia. American Economic Review, 96(3): 847-862.

Angrist, J., Bettinger, E., Bloom, E., King, E. \& Kremer, M. 2002. Vouchers for private schooling in Colombia: evidence from a randomized natural experiment. American Economic Review, 92(5): 1535-1558.

Aslam, M. 2009. The relative effectiveness of government and private schools in Pakistan: are girls worse off? Education Economics, 17(3): 329-354.

Barrera-Osorio, F., Blakeslee, D. S., Hoover, M., Linden, L. L., Raju, D. \& Ryan, S. 2013. Leveraging the private sector to improve primary school enrolment: evidence from a randomized controlled trial in Pakistan. Working Paper. Available: https://www.rise.ox.ac.uk/sites/www.rise.ox.ac.uk/ files/7 Barrera pprs pakistan working paper.pdf

Baum, D., Lewis, L., Lusk-Stover, O. \& Patrinos, H. 2014. What matters most for engaging the private sector in education: A framework paper. Washington, DC: World Bank.

Chudgar, A. \& Quin, E. 2012. Relationship between private schooling and achievement: results from rural and urban India. Economics of Education Review, 31(4): 376-390.

Desai, S., Dubey, A., Vanneman, R. \& Banerji, R. 2008. Private schooling in India: a new educational landscape. India Human Development Survey Working Paper No. 11.

Draper, K. \& Hofmeyr, J. 2015. Low-fee private schools: international experience and South African realities. Johannesburg: Centre for Development and Enterprise.

French, R. \& Kingdon, G. 2010. The relative effectiveness of private and government schools in rural India: evidence from ASER data. Department of Quantitative Social Science Working Paper No. 10-03.

Goyal, S. \& Pandey, P. 2009. How do government and private schools differ? Findings from two large Indian states. Washington, DC: World Bank.

Goyal, S. 2009. Inside the house of learning: the relative performance of public and private schools in Orissa. Education Economics, 17(3): 315-327.

Härmä, J. 2009. Can choice promote Education for All? Evidence from growth in private primary schooling in India. Compare: A Journal of Comparative and International Education, 39(2): 151-165.

Härmä, J. 2013. Access or quality? Why do families living in slums choose low-cost private schools in Lagos, Nigeria? Oxford Review of Education, 39(4): 548-566.

Hofmeyr, J., McCarthy, J., Oliphant, R., Schirmer, S. \& Bernstein, A. 2013. Affordable private schools in South Africa. Johannesburg: Centre for Development and Enterprise.

Javaid, K., Musaddiq, T. \& Sultan, A. 2012. Prying the private school effect: an empirical analysis of learning outcomes of public and private schools in Pakistan. Lahore: University of Management

Kingdon, G. 1996. The quality and efficiency of private and public education: a case study of urban India. Oxford Bulletin of Economics and Statistics, 58(1): 57-82. 
KwaZulu-Natal School Education Act, 1996 (Act 3 of 1996). Notice regarding the registration and payment of subsidies to independent schools. Pietermaritzburg.

Lewin, K. M. 2007. The limits to growth of non-government private schooling in Sub-Saharan Africa. CREATE Pathways to Access Research Monograph No. 5.

Muralidharan, K. \& Kremer, M. 2009. Public and private schools in rural India. In School Choice International: Exploring Public-Private Partnerships. R. Chakrabarti \& P. Peterson, Eds. Cambridge, MA: MIT Press.

Muralidharan, K. \& Sundararaman, V. 2013. The aggregate effect of school choice: evidence from a twostage experiment in India. NBER Working Paper No. 19441.

Schirmer, S., Johnston, S. \& Bernstein, A. 2010. Hidden assets: South Africa's low-fee private schools. Johannesburg: Centre for Development and Enterprise.

Singh, A. 2013. Size and sources of the private school premium in test scores in India. Young Lives Working Paper 98.

South African Schools Act, 1996 (Act 84 of 1996). Notice for the registration and subsidy of independent schools. Pretoria.

Thapa, A. 2012. Public and private school performance in Nepal: an analysis using the SLC examination. Education Economics, 23(1): 47-62.

Tooley, J. \& Dixon, P. 2006. 'De facto' privatisation of education and the poor: implications of a study from sub-Saharan Africa and India. Compare: A Journal of Comparative and International Education, 36(4)443-462.

Tooley, J. \& Longfield, D. 2014. The role and impact of private schools in developing countries: a response to DFID's "Rigorous Literature Review". E.G. West Centre Working Paper.

Van der Berg, S. 2015. What the Annual National Assessments can tell us about learning deficits over the education system and the school career. South African Journal of Childhood Education 5(2): 2843.

Wadhwa, W. 2009. Are private schools really performing better than government schools? New Delhi: ASER.

Western Cape Provincial Education Act, 1997 (Act 12 of 1997). Regulations relating to the registrations of and subsidies to independent schools (excluding independent pre-primary schools), 6 December 2011. Cape Town. 
Appendix Table 1: Regressions of school performance in ANA Mathematics, 2012: School fees and schools resources ('costs')

\begin{tabular}{|c|c|c|c|c|c|c|c|c|c|c|c|c|}
\hline & \multicolumn{3}{|c|}{ Western Cape primary } & \multicolumn{3}{|c|}{ Gauteng primary } & \multicolumn{3}{|l|}{ SA primary } & \multicolumn{3}{|c|}{ SA Secondary } \\
\hline & All & $\begin{array}{l}\text { Excluding } \\
\text { decile } 10\end{array}$ & $\begin{array}{l}\text { Excludin } \\
\text { g deciles } \\
9 \& 10\end{array}$ & All & $\begin{array}{l}\text { Excludin } \\
\text { g decile } \\
10\end{array}$ & $\begin{array}{l}\text { Excludin } \\
\text { g deciles } \\
9 \& 10\end{array}$ & All & $\begin{array}{l}\text { Excluding } \\
\text { decile } 10\end{array}$ & \begin{tabular}{|l} 
Excluding \\
deciles $9 \&$ \\
10
\end{tabular} & All & $\begin{array}{l}\text { Excludin } \\
\mathrm{g} \text { decile } \\
10\end{array}$ & $\begin{array}{l}\text { Excludi } \\
\text { ng } \\
\text { deciles } \\
9 \& 10\end{array}$ \\
\hline $\begin{array}{l}\text { Independe } \\
\text { nt dummy }\end{array}$ & $\begin{array}{l}- \\
12.524^{* *} \\
*\end{array}$ & $-6.706^{*}$ & -3.262 & $2.913^{*}$ & $\begin{array}{l}5.000^{* *} \\
*\end{array}$ & $\begin{array}{l}7.472^{* *} \\
*\end{array}$ & $-5.595 * * *$ & 4.562 & -19.633 & -2.58 & 2.323 & -5.127 \\
\hline $\log$ fee & $0.865^{* * *}$ & $0.866^{* * *}$ & $\begin{array}{l}0.832 * * \\
*\end{array}$ & $\begin{array}{l}0.219 * * \\
*\end{array}$ & $\begin{array}{l}0.248^{* *} \\
*\end{array}$ & $\begin{array}{l}0.232 * * \\
*\end{array}$ & $0.406^{* * *}$ & $0.347^{* * *}$ & $0.435^{*}$ & $0.197^{* * *}$ & $\begin{array}{l}0.173 * * \\
*\end{array}$ & 0.256 \\
\hline$(\log$ fees)^2 & $0.560 * * *$ & $0.568^{* * *}$ & $\begin{array}{l}0.515^{* *} \\
*\end{array}$ & $\begin{array}{l}0.224^{* *} \\
*\end{array}$ & $\begin{array}{l}0.153^{* *} \\
*\end{array}$ & $\begin{array}{l}0.101^{* *} \\
*\end{array}$ & $0.256^{* * *}$ & $0.253^{* * *}$ & 0.196 & $0.092^{* * *}$ & $0.110^{* *}$ & 0.084 \\
\hline Enrolment & $\begin{array}{l}- \\
0.007^{* * *}\end{array}$ & $\begin{array}{l}- \\
0.007^{* * *}\end{array}$ & $\begin{array}{l}- \\
0.008^{* *} \\
*\end{array}$ & $\begin{array}{l}- \\
0.002 * *\end{array}$ & $\begin{array}{l}- \\
0.003 * *\end{array}$ & $-0.002^{*}$ & $-0.008 * * *$ & $-0.008 * * *$ & $-0.008 * * *$ & $\begin{array}{l}- \\
0.006 * * *\end{array}$ & $\begin{array}{l}- \\
0.006 * * \\
*\end{array}$ & $\begin{array}{l}-\overline{-} \\
0.005^{* *} \\
*\end{array}$ \\
\hline Urban & 1.138 & 1.097 & 1.514 & -1.436 & -0.912 & -0.967 & 0.378 & $0.641^{*}$ & $0.813^{* *}$ & $-0.665^{*}$ & $-0.743^{*}$ & -0.603 \\
\hline Constant & $17.2^{* * *}$ & $17.0^{* * *}$ & $19.8^{* * *}$ & $27.8^{* * *}$ & $30.9 * * *$ & $33.1^{* * *}$ & $26.4^{* * *}$ & $26.0^{* * *}$ & $29.4^{* * *}$ & $15.3^{* * *}$ & $14.3^{* * *}$ & 15.9 \\
\hline R-squared & 0.519 & 0.467 & 0.293 & 0.253 & 0.152 & 0.106 & 0.125 & 0.038 & 0.026 & 0.038 & 0.028 & 0.02 \\
\hline $\mathrm{N}$ & 1103 & 1056 & 960 & 1257 & 1146 & 1037 & 12381 & 11448 & 10215 & 2982 & 2922 & 2799 \\
\hline F statistic & 236.413 & 183.699 & 78.89 & 84.785 & 40.798 & 24.425 & 353.751 & 91.611 & 55.178 & 23.257 & 17.088 & 11.589 \\
\hline
\end{tabular}




\begin{tabular}{|c|c|c|c|c|c|c|c|c|c|c|c|c|}
\hline & \multicolumn{3}{|c|}{ Western Cape primary } & \multicolumn{3}{|c|}{ Gauteng primary } & \multicolumn{3}{|l|}{ SA primary } & \multicolumn{3}{|c|}{ SA Secondary } \\
\hline & All & $\begin{array}{l}\text { Excluding } \\
\text { decile } 10\end{array}$ & $\begin{array}{l}\text { Excludin } \\
\text { g deciles } \\
9 \& 10\end{array}$ & All & $\begin{array}{l}\text { Excludin } \\
\text { g decile } \\
10\end{array}$ & $\begin{array}{l}\text { Excludin } \\
\text { g deciles } \\
9 \& 10\end{array}$ & All & \begin{tabular}{|l|} 
Excluding \\
decile 10
\end{tabular} & $\begin{array}{l}\text { Excluding } \\
\text { deciles } 9 \& \\
10\end{array}$ & All & $\begin{array}{l}\text { Excludin } \\
\text { g decile } \\
10\end{array}$ & $\begin{array}{l}\text { Excludi } \\
\text { ng } \\
\text { deciles } \\
9 \& 10\end{array}$ \\
\hline $\begin{array}{l}\text { Independe } \\
\text { nt dummy }\end{array}$ & $4.168^{*}$ & $\begin{array}{l}24.269 * * \\
*\end{array}$ & $\begin{array}{l}26.48^{* *} \\
*\end{array}$ & $\begin{array}{l}10.50^{* *} \\
*\end{array}$ & $\begin{array}{l}11.19^{* *} \\
*\end{array}$ & $\begin{array}{l}12.12^{* *} \\
*\end{array}$ & $2.551^{* *}$ & $10.663^{* * *}$ & $-49.984 * *$ & 0.661 & 6.329 & 12.359 \\
\hline log of costs & $\begin{array}{l}688.71^{* *} \\
*\end{array}$ & $\begin{array}{l}512.579 * \\
*\end{array}$ & $\begin{array}{l} \\
155.485\end{array}$ & -28.196 & -2.399 & 20.592 & $\begin{array}{l}196.456^{* *} \\
*\end{array}$ & $\begin{array}{l}- \\
1004.62 * * \\
*\end{array}$ & $\begin{array}{l}- \\
2567.961^{*} \\
*\end{array}$ & $\begin{array}{l}74.706^{* *} \\
*\end{array}$ & $\begin{array}{l}- \\
381.950 \\
*\end{array}$ & 1122.97 \\
\hline $\begin{array}{l}(\log \\
\text { costs)^2 }\end{array}$ & $\begin{array}{l}- \\
32.698 * * \\
*\end{array}$ & $\begin{array}{l}- \\
23.271 * *\end{array}$ & 12.135 & 1.951* & 0.644 & -0.527 & $-8.896 * * *$ & $54.345^{* * *}$ & $137.014^{* *}$ & $-3.366 * *$ & $20.515^{*}$ & -59.658 \\
\hline Enrolment & $\begin{array}{l}- \\
0.007^{* * *}\end{array}$ & $\begin{array}{l}- \\
0.007 * * *\end{array}$ & $\begin{array}{l}- \\
0.008 * * \\
*\end{array}$ & $-0.002^{*}$ & $-0.002^{*}$ & $-0.002^{*}$ & $-0.006 * * *$ & $-0.007^{* * *}$ & $-0.008 * * *$ & $\begin{array}{l}- \\
0.005^{* * *}\end{array}$ & $\begin{array}{l}- \\
0.005^{* *} \\
*\end{array}$ & $\begin{array}{l}- \\
0.005^{* *} \\
*\end{array}$ \\
\hline Urban & $2.321 * * *$ & $2.055^{* *}$ & \begin{tabular}{|l|}
$2.800^{* *}$ \\
$*$
\end{tabular} & -1.212 & -0.849 & -0.891 & $0.725^{* *}$ & $0.755^{* *}$ & $0.619 *$ & $-0.733^{*}$ & $-0.761 *$ & -0.529 \\
\hline Constant & $\begin{array}{l}- \\
3544.9 * * \\
*\end{array}$ & $\begin{array}{l}- \\
2722.4^{* *}\end{array}$ & 429.1 & 130.0 & 2.8 & -109.9 & - $1025.4^{* * *}$ & $4676.7^{* * *}$ & $12067.7^{* *}$ & $\begin{array}{l}- \\
386.5^{* * *}\end{array}$ & $1795.9 *$ & -5266.3 \\
\hline R-squared & 0.480 & 0.444 & 0.269 & 0.283 & 0.168 & 0.119 & 0.116 & 0.037 & 0.028 & 0.035 & 0.028 & 0.02 \\
\hline $\mathrm{N}$ & 1103 & 1056 & 960 & 1257 & 1146 & 1037 & 12381 & 11448 & 10215 & 2982 & 2922 & 2799 \\
\hline F statistic & 202.438 & 167.99 & 70.165 & 98.929 & 45.999 & 27.757 & 324.962 & 89.091 & 57.851 & 21.446 & 16.765 & 11.476 \\
\hline
\end{tabular}

${ }^{*} p<0.1,{ }^{* *} p<0.05,{ }^{* * *} p<0.01$ 